\title{
ANALISIS PEMOTONGAN PIPA PRODUKSI SUMUR MINYAK DENGAN TEKNIK HYDRAJETTING MENGGUNAKAN FLUIDA ABRASIF DAN POMPA BERTEKANAN TINGGI
}

\author{
Komarudin $^{1}$, Taufik Rachmat Rakean Kalangsunda ${ }^{2}$ \\ Program Studi Teknik Mesin, Institut Sains dan Teknologi Nasional ${ }^{12}$ \\ email ${ }^{1}$ : komarudin.mt@gmail.com
}

\begin{abstract}
An oil production well own by Company $\mathrm{X}$ had its production declined due to the impact of corrosion and scaling issues which happened on the production tubing. To solve the problem, an immediate action was made to replace the production tubing through a Hydrajetting cutting process which combining the abrasive fluid and high pressure pump application. The scope of subject were limited to process analyzing and calculation which happened during the production tubing cutting process. Analysis was done through fluid mechanic principle with the usage of the Energy Conservation Theory to get an accurate result of a successful Hydrajetting cutting process for production tubing. Analysis method was used to calculate all the data which includes fluid velocity, pressure, energy, and all the other related factors. The result of the calculation will be compared to the Hydrajetting recommendation standard. The result from the analysis will prove and explain a successful Hydrajetting cutting process for production tubing and provide a quality measured solution to solve the problem happened on the oil production well due to damage occurred on its production tubing.
\end{abstract}

Kata kunci: Energy Conservation Theory, Hydrajetting, Abrasive Fluid

\section{PENDAHULUAN}

Minyak bumi merupakan sumber komoditas yang sangat penting bagi kehidupan manusia mulai zaman dahulu sampai saat ini. Kawasan Timur Tengah merupakan penghasil minyak bumi terbesar dari keseluruhan produksi dunia. Suatu sumur produksi milik Perusahaan X di kawasan ini mengalami penurunan produksi yang diakibatkan oleh permasalahan korosi dan scaling yang terjadi pada pipa produksinya. Untuk mengembalikan hasil produksi pada targetnya maka dilakukan perbaikan berupa penggantian pipa produksi yang baru. Pada tahap penggantian dilakukan

proses pemotongan terlebih dahulu dimana pipa produksi sumur dipotong menjadi dua bagian. Bagian pipa produksi yang mengalami kerusakan selanjutnya akan dicabut ke permukaan dan dipasang pipa yang baru. Proses pemotongan pipa produksi ini dilakukan dengan teknik Hydrajetting dengan menggunakan fluida abrasif dan pompa bertekanan tinggi

\section{TINJAUAN PUSTAKA}

Sumur produksi adalah sumur yang menghasilkan sesuatu yang bernilai atau bermanfaat seperti minyak bumi, gas bumi, panas bumi, air, mineral atau komponen-komponen lain yang berasal dari dalam perut bumi. Proses produksi sumur dapat terjadi secara alami atau artificial lift. Aliran produksi alami dapat terjadi karena tekanan dari dalam bumi cukup besar untuk melawan tekanan hidrostatik fluida dalam sumur sehingga terjadi aliran deposit dari reservoir sampai ke permukaan. Proses produksi secara artificial lift membutuhkan alat berupa pompa untuk mengalirkan deposit ke permukaan. Hal ini dikarenakan tekanan dari dalam bumi tidak cukup untuk melawan tekanan hidrostatik fluida dalam sumur. Suatu sumur produksi terdiri dari beberapa komponen yaitu kepala sumur atau wellhead, pipa casing, pipa produksi, perforasi, semen, packer, pompa dan macam macam aksesoris yang lain.

Wireline Logging CAST Ultrasonic Tubing And Casing Evaluation

Pemeriksaan terhadap pipa produksi dilakukan melalui metode Wireline Logging CAST Ultrasonic Tubing and Casing Evaluation yang menggunakan teknologi ultrasonic untuk mendeteksi ketebalan pipa produksi yang ada didalam sumur. Alat CAST dihantarkan ke dalam pipa produksi sumur dan akan memberikan data terjadinya korosi yang dapat berakibat munculnya lubang atau kebocoran pada 
pipa produksi. Selain itu alat ini juga menghasilkan model secara 3-Dimensi yang memperlihatkan area pipa yang mengalami penipisan ketebalan.

\section{Alat-alat yang digunakan pada proses pemotongan pipa produksi sumur dengan teknik Hydrajetting}

1. Coiled Tubing berfungsi untuk menghantarkan suatu alat atau fluida pada kedalaman yang ditentukan.

2. Unit Coiled Tubing, berfungsi untuk menghantarkan pipa coiled tubing masuk ke dalam dan keluar sumur untuk melakukan pekerjaan peningkatan produksi sumur.

3. Pompa Bertekanan Tinggi berfungsi untuk mendorong fluida abrasif ke dalam pipa coiled tubing hingga keluar dari nozel dan kembali ke permukaan.

4. Alat HydraBlast ${ }^{T M}$ adalah alat yang dirancang untuk aplikasi coiled tubing yang memiliki lubang nozel yang kecil pada kepala potong (cutting head) yang dapat berputar. Fluida yang dialirkan oleh pompa bertekanan tinggi dan keluar dari lubang nozel yang kecil akan memiliki tekanan dan energi yang cukup besar.

5. Retrivable Bridge Plug Packer adalah sebuah alat yang digunakan untuk mengisolasi produksi sumur. Pada alat ini terdapat elemen karet yang akan menempel pada permukaan dalam pipa produksi dan menahan aliran produksi ke permukaan. Retrivable Bridge Plug Packer akan dipasang di bawah area pipa produksi yang mengalami kerusakan untuk mengisolasi sementara produksi minyak dari dalam bumi sampai penggantian pipa produksi yang baru sudah selesai.

\section{Prosedur Teknik Hydrajetting}

1. Pasang alat HydraBlast ${ }^{T M}$ pada pipa coiled tubing. Lakukan pemompaan guna menguji coba fungsi putaran dan amati fluida yang keluar dari setiap nozel yang terdapat pada kepala (head) HydraBlast $^{T M}$. Monitor dan catat tekanan pompa dan laju aliran fluida.

2. Buka valve kepala sumur dan hantarkan alat HydraBlast $^{T M}$ pada kedalaman yang telah ditentukan. Monitor selalu tekanan sumur, berat dan tekanan dalam pipa coiled tubing saat proses penghantaran.

3. Setelah alat HydraBlast ${ }^{T M}$ sampai pada kedalaman yang diinginkan, mulai pompakan fluida abrasif melalui pipa coiled tubing. Monitor tekanan pompa, tekanan coiled tubing dan tekanan sumur.

4. Pada saat fluida abrasif mencapai kepala (cutting head) maka kepala HydraBlast ${ }^{T M}$ akan berputar dan fluida abrasif akan disemburkan keluar dari nozel dengan tekanan tinggi. Fluida abrasif yang keluar dari nozel tersebut akan mengenai permukaan dalam pipa produksi dan melakukan proses pengikisan hingga akhirnya terjadi pemotongan.

5. Setelah seluruh fluida abrasif telah habis dipompakan, pipa coiled tubing beserta alat HydraBlast $^{T M}$ akan dicabut kembali ke permukaan.

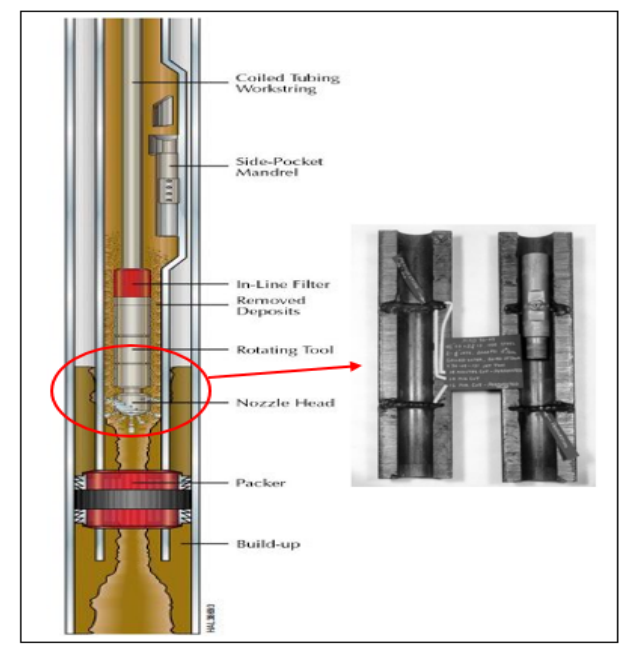

Gambar 7. Proses Pemotongan Pipa.

6. Selanjutnya diteruskan dengan kegiatan rig workover untuk mencabut pipa yang sudah dipotong dan mengganti dengan pipa produksi yang baru. Kemudian Retrievable Bridge Plug Packer akan dicabut sehingga sumur dapat berproduksi kembali.

\section{Persamaan Kontinuitas}

Persamaan kontinuitas adalah persamaan yang menghubungkan kecepatan fluida dari satu tempat ke tempat lain. Kecepatan fluida akan berubah seiring dengan perubahan diameter atau luas penampang saluran yang dilewatinya.

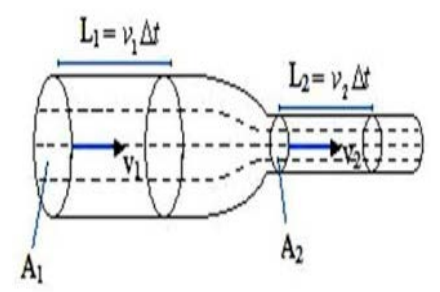

Gambar 8. Aliran fluida dalam pipa

\section{Rumus :}

$$
\begin{aligned}
\mathbf{m}_{1} & =\mathbf{m}_{2} \\
\rho_{1} A_{1} V_{1} & =\rho_{2} A_{2} V_{2}
\end{aligned}
$$

Dimana :

$$
\begin{aligned}
& m=\text { Laju aliran massa }(\mathrm{kg} / \mathrm{s}) \\
& \rho=\operatorname{Kerapatan} \text { fluida }\left(\mathrm{kg} / \mathrm{m}^{3}\right) \\
& A=\text { Luas penampang }\left(\mathrm{m}^{2}\right) \\
& V=\operatorname{Kecepatan} \text { aliran fluida }(\mathrm{m} / \mathrm{s})
\end{aligned}
$$


Perkalian antara luas penampang dan kecepatan fluida pada setiap titik sepanjang tabung aliran adalah konstan.

Karena, $\mathbf{Q}=\mathbf{A} \mathbf{x} \mathbf{V}$ adalah konstan maka persamaan kontinuitas dapat berbentuk :

$\mathbf{m}=\rho_{1} \times Q_{1}=\rho_{2} \times Q_{2}$

Dimana :

$$
\left.\mathrm{Q}=\text { Debit / Kapasitas ( } \mathrm{m}^{3} / \mathrm{s}\right)
$$

\section{Teori Konservasi Energi}

Hukum Bernoulli mengatakan bahwa jika aliran fluida bertambah maka tekanan dalam fluida menjadi berkurang. Dengan adanya perbedaan tekanan maka fluida akan mengalir. Adanya tekanan dan kecepatan ini maka dapat dihitung energi yang terjadi pada aliran. Teori ini yang dimanakan Teori Konservasi Energi. Perbedaan ketinggian atau elevasi akan mempengaruhi energi yang dihasilkan. Pada aliran fluida dalam suatu saluran pipa berlaku hukum kekekalan energi.

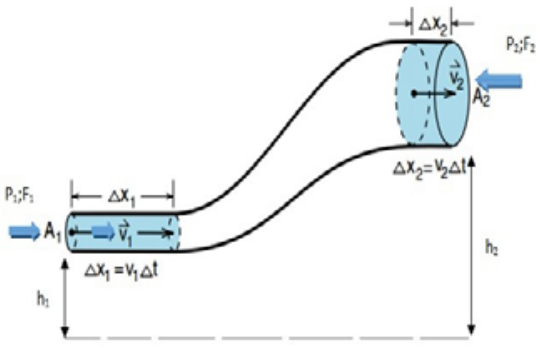

Gambar 9. Persamaan Energi Bernoulli

\section{Rumus :}

$\frac{P}{Y}+\frac{V^{2}}{2 g}+\mathrm{y}=$ konstan (Persamaan Bernoulli)

Dimana :

$\underline{\boldsymbol{P}}=$ energi tekanan .... (Static Pressure)

$\frac{v_{v}}{2 g}=$ energi kinetik .... (Dinamic Pressure)

$\mathrm{y}=$ energi potensial .... (Hydrostatic Pressure)

\section{Energi Aktual Yang Timbul Pada Aliran}

Pada kasus fluida yang mengalir dalam pipa, perhitungan energi tidak cukup hanya dengan menggunakan persamaan Bernoulli. Oleh karena itu untuk mendapatkan perhitungan yang tepat maka persamaan Bernoulli harus diubah atau disesuaikan. Rumus : $\frac{P_{1}}{\gamma}+\frac{V_{1}^{2}}{2 g}+\mathrm{y}_{1}=\frac{P_{2}}{\gamma}+\frac{V_{2}^{2}}{2 g}+\mathrm{y}_{2}+\mathbf{H}_{\mathrm{L}}$

$\mathrm{H}_{\mathrm{L}}=$ kehilangan energi atau rugi-rugi

Rumus : $\mathbf{H}_{\mathrm{L}}=\mathbf{H}_{\text {major }}+\mathbf{H}_{\text {minor }}$ $\mathrm{H}_{\text {maj }}=$ rugi-rugi besar (Major Losses)

$\mathrm{H}_{\min }=$ rugi-rugi kecil (Minor Losses)
Rugi-rugi Besar (major losses) disebabkan oleh gesekan fluida dengan permukaan dinding dalam pipa.

Rumus : $\mathbf{H}_{\text {maj }}=\mathbf{f} \times \frac{L}{D} \times \frac{V^{2}}{2 g}$

Pengaruh kekasaran permukaan $\mathrm{f}$ ditentukan oleh kondisi aliran didalam saluran atau pipa. Kondisi aliran ini ditentukan oleh bilangan Reynold (Re)

Rumus : $\mathbf{R e}=\frac{\mathrm{VD}_{\rho}}{\mu}$

Dimana:

$\mathrm{f}=$ koefisien gesek / kekasaran permukaan

$\mathrm{L}=$ panjang pipa $(\mathrm{m})$

$\mathrm{D}=$ diameter pipa $(\mathrm{m})$

$\mathrm{V}=$ kecepatan aliran $(\mathrm{m} / \mathrm{s})$

$\rho=$ kerapatan $(\mathrm{kg} / \mathrm{m} 3)$

$\mu=$ viskositas dinamik fluida (N.s/m2) atau $(\mathrm{kg} / \mathrm{m} . \mathrm{s})$

Tipe aliran fluida :

- Laminer ..... Re $<2300-4000$

Aliran laminer adalah aliran fluida yang relatif mempunyai kecepatan rendah dan fluidanya bergerak sejajar.

Koefisiensi gesek f Laminer

Rumus: $\mathrm{f}=\frac{64}{R e}$

- Turbulen ..... Re $>2300$

Aliran turbulen adalah aliran fluida yang partikel-partikelnya bergerak secara acak dan tidak stabil dengan kecepatan berfluktuasi yang saling interaksi.

Besarnya f menutut Haaland

Rumus :

$\frac{1}{f^{1 / 2}}=-1.8 \log \left[\frac{6.9}{R e}+\left(\frac{\varepsilon / D}{3.7}\right)\right]^{1.11}$

Besarnya f menurut C.F. Coolebrook

Rumus : $\frac{1}{f^{1 / 2}}=-2 \log \left[\frac{6.9}{\operatorname{Re}}+\frac{2.51}{\operatorname{Re} \sqrt{f}}\right]$

Dimana

$\varepsilon=$ tinggi kekasaran permukaan

$\mathrm{D}=$ Diameter saluran

- Rugi-rugi kecil (Minor losses) terjadi karena saat fluida mengalir melalui suatu profil berupa perbedaan diameter, lubang, belokan, persimpangan, katup, dll. Untuk menentukan besarnya rugi-rugi kecil harus menghitung rugirugi di setiap profil dan menjumlahkannya menjadi total rugi-rugi kecil.

Rumus : $\mathbf{H}_{\min }=\mathbf{K}_{\mathrm{L}} \times \frac{V^{2}}{2 g}$ 
Dimana :

$\mathrm{K}_{\mathrm{L}}=$ Koefisien Hilang

$\mathrm{V}=$ Kecepatan Aliran (m/s)

$\mathrm{g}=$ Gaya Grafitasi $\left(9,81 \mathrm{~m} / \mathrm{s}^{2}\right)$

Dengan adanya kehilangan atau rugi-rugi yang terjadi pada aliran maka secara lengkap rumus Bernoulli yang disesuaikan menjadi :

\section{Rumus :}

$\frac{P_{1}}{\gamma}+\frac{V_{1}^{2}}{2 g}+\mathbf{y}_{1}=\frac{P_{2}}{\gamma}+\frac{V_{2}^{2}}{2 g}+\mathbf{y}_{2}+\frac{V^{2}}{2 g}\left(\mathbf{f} \times \frac{L}{D}+\mathbf{K}_{\mathrm{L}}\right)$

\section{Kecepatan Dan Laju Aliran Pada Nozel}

Pada sistem aliran dalam keadaan tertutup, untuk menghitung laju aliran maka digunakan rumus Bernoulli pada prinsip laju aliran horizontal

Rumus : $\mathbf{Q}=\mathbf{A}_{2} \sqrt{\frac{2\left(p_{1}-p_{2}\right)}{\rho\left\{1-\left(\frac{A 2}{A 1}\right)^{2}\right\}}}$

Dimana :

$$
\begin{aligned}
& \mathrm{Q}=\text { debit } / \text { kapasitas }\left(\mathrm{m}^{3} / \mathrm{s}\right) \\
& \mathrm{A}=\text { luas penampang saluran } / \text { pipa }\left(\mathrm{m}^{2}\right) \\
& \mathrm{V}=\operatorname{kecepatan} \text { aliran }(\mathrm{m} / \mathrm{s}) \\
& \rho=\operatorname{kerapatan}\left(\mathrm{kg} / \mathrm{m}^{3}\right) \\
& \mathrm{P}=\operatorname{tekanan}\left(\mathrm{Pa} \text { atau } \mathrm{N} / \mathrm{m}^{2}\right)
\end{aligned}
$$

Jetting Pressure (HydraJetting Playbook, Sharlene Lindsay,2011)

Jetting Pressure adalah tekanan yang terjadi pada saat aliran melewati nozel dan dipengaruhi oleh rugi-rugi.

$$
\text { Rumus : } \mathbf{P}_{\text {Jet }}=\frac{P_{\text {nozel }} \boldsymbol{x} \text { A HydraBlast }}{A \text { Nozel }}-\mathbf{P}_{\min }
$$

Dimana :

$\mathrm{P}$ jet = jetting pressure atau tekanan jet (psi)

$\mathrm{P}$ nozel = tekanan pada nozel (psi)

$\mathrm{A}=$ luas penampang (inches ${ }^{2}$ )

$\mathrm{P}_{\text {min }}=$ rugi-rugi minor pada nozel

\section{Gaya (Force) Jetting (HydraJetting Playbook,} Sharlene Lindsay,2011)

Jetting Force merupakan gaya yang terjadi akibat dari aliran yang bertekanan dan kecepatan aliran pada nozel

Rumus : $\mathbf{F}_{\text {Jetting }}=\frac{\frac{Q \text { Jet }}{\text { Iml nozel } x \text { P Jet }}}{V}$

Dimana :

$\mathrm{F}$ jet = gaya yang terjadi pada saat jetting

$\mathrm{Q}$ jet = debit aliran pada saat jetting $(\mathrm{gal} / \mathrm{min})$

$\mathrm{P}$ Jet $=$ jetting pressure $(\mathrm{psi})$

$\mathrm{V}=$ kecepatan aliran keluar dari nozel (ft/s)
Slip Velocity (HydraJetting Playbook, Sharlene Lindsay,2011)

Slip velocity atau kecepatan gelincir adalah perbedaan kecepatan antara 2 zat yang berbeda (padat dan cair) dalam suatu campuran yang mengalir secara vertikal dalam suatu pipa.

\section{Rumus :}

$\mathrm{SV}=\frac{175 x P D x(\rho \text { partikel- } \rho \text { cairan })^{0.667}}{\rho_{\text {cairan }}{ }^{0.333} x c p^{0.333}}$

Dimana :

$$
\begin{aligned}
& \text { SV = slip velocity }(\mathrm{ft} / \mathrm{min}) \\
& 175=\text { konstanta } \\
& \mathrm{PD}=\text { diameter partikel (inches) } \\
& \rho \text { partikel = kerapatan partikel }(\mathrm{lbm} / \mathrm{gal}) \\
& \rho \text { cairan= kerapatan cairan }(\mathrm{lbm} / \mathrm{gal}) \\
& \mathrm{Cp}=\text { viskositas cairan }(\mathrm{cp})
\end{aligned}
$$

Annular Velocity (HydraJetting Playbook, Sharlene Lindsay, 2011)

Annular velocity atau kecepatan anulus adalah kecepatan aliran fluida dalam annulus. Anulus sendiri diartikan sebagai daerah atau area yang terdapat diantara dua pipa. Berikut adalah rumus rekomendasi annular velocity dengan pertimbangan slip velocity.

Rumus : $\mathbf{A V}=\mathbf{S V} \times \mathbf{S F}$

Dimana :

$\mathrm{AV}=$ annular velocity $(\mathrm{ft} / \mathrm{s})$

$\mathrm{SV}=$ slip velocity $(\mathrm{ft} / \mathrm{min})$

$\mathrm{SF}=$ safety factor $($ rekomendasi $\mathrm{SF}=5$ )

\section{Tekanan Burst (Burst Pressure) dan Gaya Burst (Burst Force)}

Burst adalah suatu keadaan dimana tekanan di dalam pipa lebih besar dari tekanan di luar pipa. Tekanan burst yang berlebih dapat mengakibatkan pipa menjadi mengembang (ballooning) bahkan pecah. Pada perhitungan tekanan Burst terdapat harga MTS (minimum tensile strength) yang didapat dari tabel pipa standard API. Burst Force atau gaya burst adalah gaya yang dibutuhkan untuk membuat pipa menjadi rusak.

\footnotetext{
Rumus Barlow :

$\mathbf{P}_{\text {burst pipa }}=\frac{2 \mathrm{xMTS} x \mathrm{t}}{\mathrm{d} x \mathrm{SF}}$

$F_{\text {burst pipa }}=\mathbf{P}_{\text {burst pipa }} \times A_{\text {Nozel }}$
}

Dimana :

$$
\begin{aligned}
& \text { P burst pipa = tekanan burst pipa (psi) } \\
& \text { MTS = Minimum Tensile Strength (psi) } \\
& \mathrm{t}=\text { ketebalan dinding pipa (inches) } \\
& \mathrm{d}=\text { diameter dalam pipa (inches) } \\
& \text { SF = Safety Factor =1 - } 1.5 \\
& \text { A = luas nozel (mm) }
\end{aligned}
$$

Standoff (HydraJetting Playbook, Sharlene Lindsay,2011) 
Standoff merupakan jarak penyimpangan antara dua posisi kesumbuan. Kondisi standoff akan berpengaruh pada lebar jarak nozel dengan target yang akan mempengaruhi jetting force yang diterima oleh target.

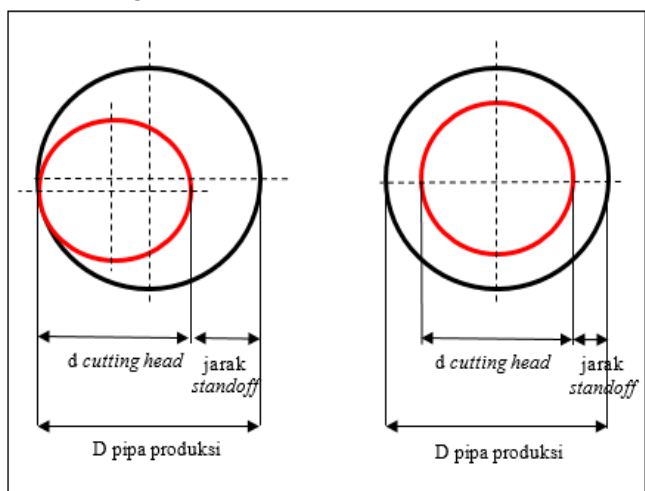

Gambar 11. Kondisi Standoff

Pada kondisi cutting head menempel pada dinding pipa produksi

Rumus :

\section{Jarak Standoff $=\mathrm{D}$ pipa produksi $-\mathrm{d}$ cutting head}

Pada kondisi sumbu cutting head berada sesumbu dengan sumbu pipa produksi

\section{Rumus \\ Jarak Standoff $=(\mathrm{D}$ pipa produksi $-\mathrm{d}$ cutting head) / 2}

\section{METODE PENELITIAN}

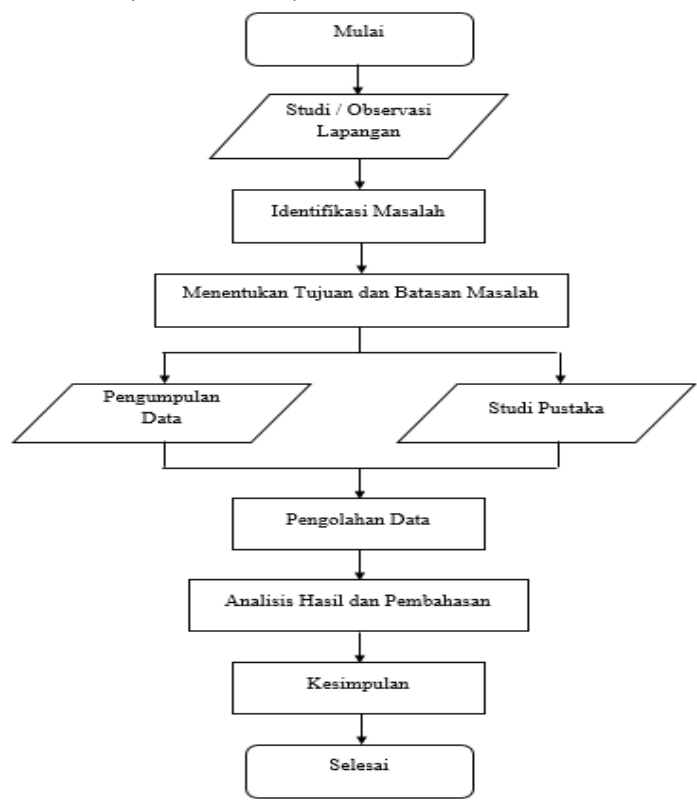

Gambar 12. Diagaram alir penelitian

\section{Prosedur Pengumpulan Data}

Data data yang diambil dan dikumpulkan di lapangan merupakan data real time dimana data terjadi pada saat proses pemotongan pipa produksi berlangsung.

- Data tekanan diukur menggunakan alat pressure transducer yang dipasang pada pompa dan kepala sumur. Proses pengambilan data tekanan ini dilakukan dengan cara memompakan fluida gel pada kedalaman potong dengan laju aliran yang berbeda-beda dan memonitor tekanan yang terjadi pada pompa, pipa coiled tubing dan kepala sumur. Data tekanan diamati pada monitor yang terdapat pada control cabin dan pompa.

- Data debit aliran diukur dengan mengunakan alat flow meter dan magnetic pick up. Pengambilan data debit ini dilakukan dengan cara memompakan fluida gel ke dalam instalasi. Data debit aliran diamati pada monitor yang terdapat pada control cabin dan pompa.

- Data viskositas fluida diakukan dengan pengukuran langsung di lapangan. Fluida yang telah dicampur di tangki dalam bentuk gel diambil sampelnya dan di test menggunakan alat Fann 35 Viscometer untuk mendapatkan kekentalan.

\section{Spesifikasi Data}

\begin{tabular}{|c|c|}
\hline \multicolumn{2}{|l|}{ Data Sumur } \\
\hline Nama Sumur & : GHZL 7 \\
\hline Lokasi & : Ghazal Field - Saudi Arabia \\
\hline Kedalaman total & $: 20035 \mathrm{ft}(6107 \mathrm{~m})$ \\
\hline Tipe Completion & : Vertical cased hole oil producer \\
\hline Pipa Casing & :9-5/8", 53.50\#, NKA; 58.40\#, V10@0-13755 ft \\
\hline Pipa Liner & :5-1/2", NKA, 20.00\#@20032ft TOL@13611ft. \\
\hline Pipa Produksi (Tubing) & : 4-1/2" $13.50 \#$ VMS Blue Series N-80TM \\
\hline Restriksi Sumur & :3.671"-R Nipple@13715ft (4180m) \\
\hline BHST & $: 281^{\circ} \mathrm{F}$ (Bottom Hole Static Temperature) \\
\hline Tekanan Reservoir & $: 4800 \mathrm{psi}\left(3.309 \times 10^{7} \mathrm{~N} / \mathrm{m}^{2}\right)$ \\
\hline $\mathrm{H} 2 \mathrm{~S}$ & $: 5 \%$ \\
\hline $\mathrm{CO} 2$ & : Tidak ada \\
\hline Fluida pada TCA & : Diesel SG 0.893 \\
\hline
\end{tabular}

Gambar 13. Data Sumur 


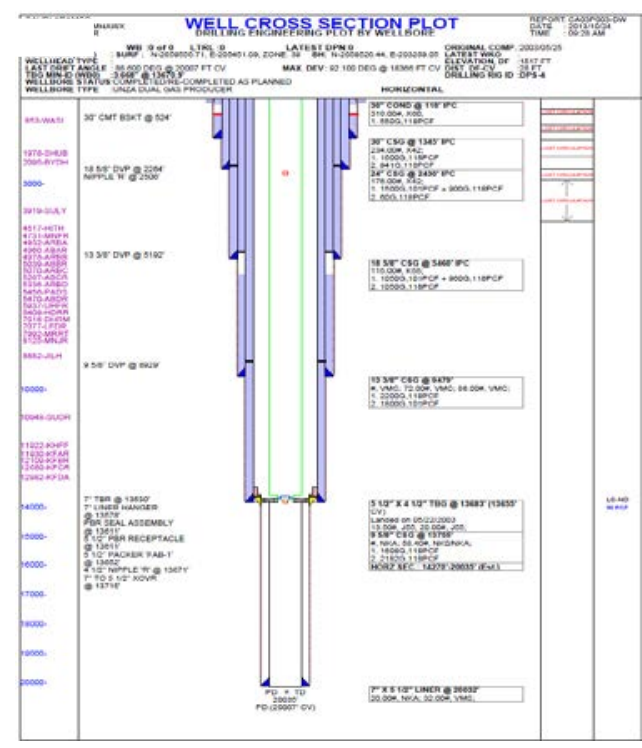

Gambar 14. Skematik sumur

\section{Data Kedalaman Posisi Potong Berdasarkan Data CAST Ultrasonic}

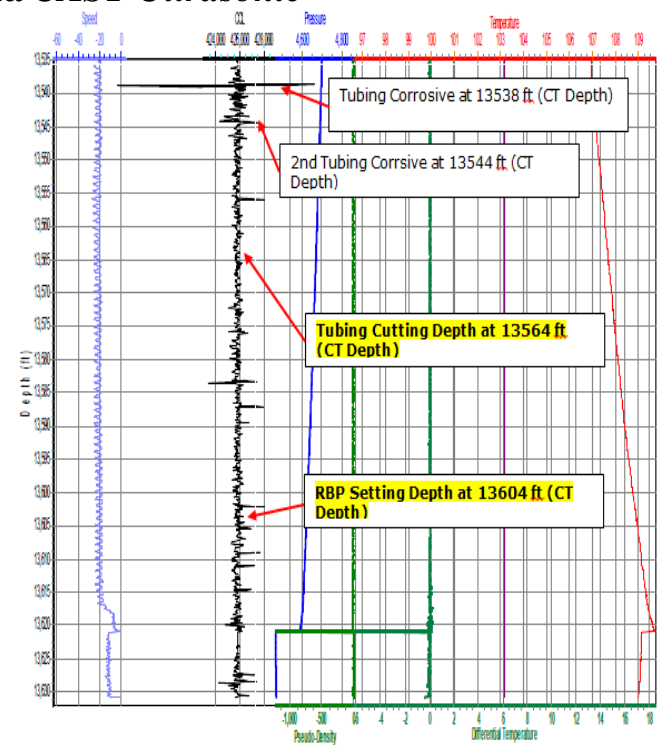

Gambar 15. Data CAST

Dari data CAST ditetapkan posisi untuk meletakkan Retrievable Bridge Plug pada kedalaman 13604 ft (4147 m), dan untuk posisi kedalaman pipa produksi yang akan di potong pada kedalaman $13564 \mathrm{ft}$ (4134 m)

\section{Data Pipa Produksi Yang Akan Dipotong}

Pipa $4 \frac{1}{2}$ “ 13.50\# VMS Blue Series N 80

Penjelasan :

$4 \frac{1}{2}$ “ : pipa OD 4.5 inch (114.3 mm)

ID 3.92 inch $=99.56 \mathrm{~mm}$

13.5 : berat pipa $13.5 \mathrm{lb} / \mathrm{ft}(20 \mathrm{~kg} / \mathrm{m})$

$\mathrm{N}-80$ : material pipa

MTS * : 100000 psi

Tabel 1. Tabel API Steel Grades

\begin{tabular}{|c|c|c|c|c|}
\hline \multicolumn{5}{|c|}{ TABLE 7.1-API STEEL GRADES } \\
\hline \multirow{2}{*}{$\begin{array}{l}\text { API } \\
\text { Grade }\end{array}$} & \multicolumn{2}{|c|}{ Yield Stress, psi } & \multirow{2}{*}{$\begin{array}{l}\text { Minimum Ult. } \\
\text { Tensile, psi }\end{array}$} & \multirow{2}{*}{$\begin{array}{c}\text { Minimum } \\
\text { Elongation, \% }\end{array}$} \\
\hline & Minimum & Maximum & & \\
\hline$H-40$ & 40,000 & 80,000 & 60,000 & 29.5 \\
\hline J-55 & 55,000 & 80,000 & 75,000 & 24.0 \\
\hline K-55 & 55,000 & 80,000 & 95,000 & 19.5 \\
\hline $\mathrm{N}-80$ & 80,000 & 110,000 & 100,000 & 18.5 \\
\hline$L-80$ & 80,000 & 95,000 & 95,000 & 19.5 \\
\hline C-90 & 90,000 & 105,000 & 100,000 & 18.5 \\
\hline C-95 & 95,000 & 110,000 & 105,000 & 18.5 \\
\hline $\mathrm{T}-95$ & 95,000 & 110,000 & 105,000 & 18.0 \\
\hline$P=110$ & 110,000 & 140,000 & 125,000 & 15.0 \\
\hline Q-125 & 125,000 & 150,000 & 135,000 & 18.0 \\
\hline
\end{tabular}

\section{Data Pipa Coiled Tubing}

Diameter Luar (OD) : : 2 inch (50,8 mm)

Diamter Dalam (ID) $\quad: 1.782$ in $(45.3 \mathrm{~mm})$

Panjang (L) : $20350 \mathrm{ft}(6206,7 \mathrm{~m})$

Skematik Alat Hydrajetting

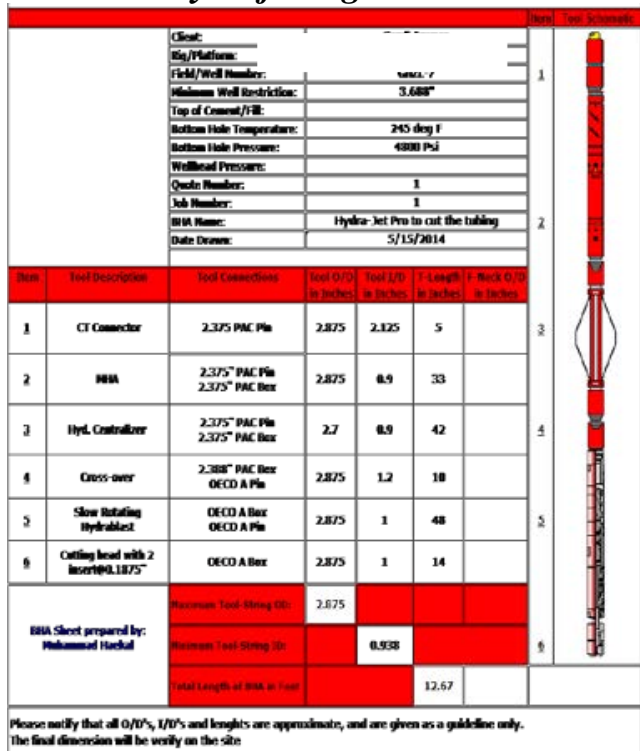

Gambar 16. Skematik Alat Hydrajetting

Ukuran Cutting Head : 2.875 inch (73 mm)

Ukuran nozel : 0.1875 inch $(4.76 \mathrm{~mm})$

Panjang alat : $12.67 \mathrm{ft}=3.86 \mathrm{~m}$

Diameter dalam (rata-rata): 1 inch $=25.4 \mathrm{~mm}$

Fluida Abrasif

- Jenis Fluida : Viscosified Water / Water Based Fluid Gel

Kerapatan Fluida : $8.34 \mathrm{PPG}=1000 \mathrm{~kg} / \mathrm{m}^{3}$ Specific Gravity (SG) : 1

Viskositas Fluida: $20 \mathrm{cp} 0.02$ Pa.s

- Jenis Pasir (Proppant) : 12/20 Ottawa Sand

Ukuran pasir : 0.0496 in (1.26 mm)

Konsentrasi Proppant : 1 PPA (lbs/added)

Kerapatan Proppant : 22.1 PPG

Specific Gravity (SG) : 2.65

\section{Data Debit Aliran vs Tekanan Pompa}

Data debit aliran dan tekanan pompa aktual yang diambil di lapangan pada saat pengetesan alat HydraBlast $^{T M}$ di dalam sumur pada kedalaman potong sebelum proses pemotongan dilakukan. 
Tabel 2. Data Debit Aliran vs Tekanan Pompa Data Debit Aliran vs Tekanan Yang Terjadi Pada Kepala Sumur

\begin{tabular}{|c|c|}
\hline Debit aliran $\left(\mathbf{m}^{\mathbf{3}} / \mathbf{s}\right)$ & Tekanan Pompa $\left(\mathbf{N} / \mathbf{m}^{\mathbf{2}}\right)$ \\
\hline 0.0026 & $2.413 \times 10^{7}$ \\
\hline 0.0039 & $3.378 \times 10^{7}$ \\
\hline $\mathbf{0 . 0 0 5 2}$ & $\mathbf{4 . 6 1 9 \times 1 0 ^ { 7 }}$ \\
\hline 0.0061 & $5.447 \times 10^{7}$ \\
\hline
\end{tabular}

Data debit aliran dan tekanan yang terjadi di kepala sumur pada saat pengetesan alat HydraBlast ${ }^{T M}$ di dalam sumur pada kedalaman potong sebelum proses pemotongan. Tes dilakukan dengan menggunakan ukuran choke keluaran 1 inch $=25.4$ $\mathrm{mm}$ (fully open choke).

Tabel 3. Debit Aliran vs Tekanan Kepala Sumur

\begin{tabular}{|c|c|}
\hline Debit aliran $\left(\mathbf{m}^{3} / \mathbf{s}\right)$ & Tekanan Kepala Sumur $\left(\mathbf{N} / \mathbf{m}^{2}\right)$ \\
\hline 0.0026 & $0.344 \times 10^{6}$ \\
\hline 0.0039 & $0.758 \times 10^{6}$ \\
\hline $\mathbf{0 . 0 0 5 2}$ & $\mathbf{1 . 0 3 4 \times 1 0 ^ { 6 }}$ \\
\hline 0.0061 & $1.379 \times 10^{6}$ \\
\hline
\end{tabular}

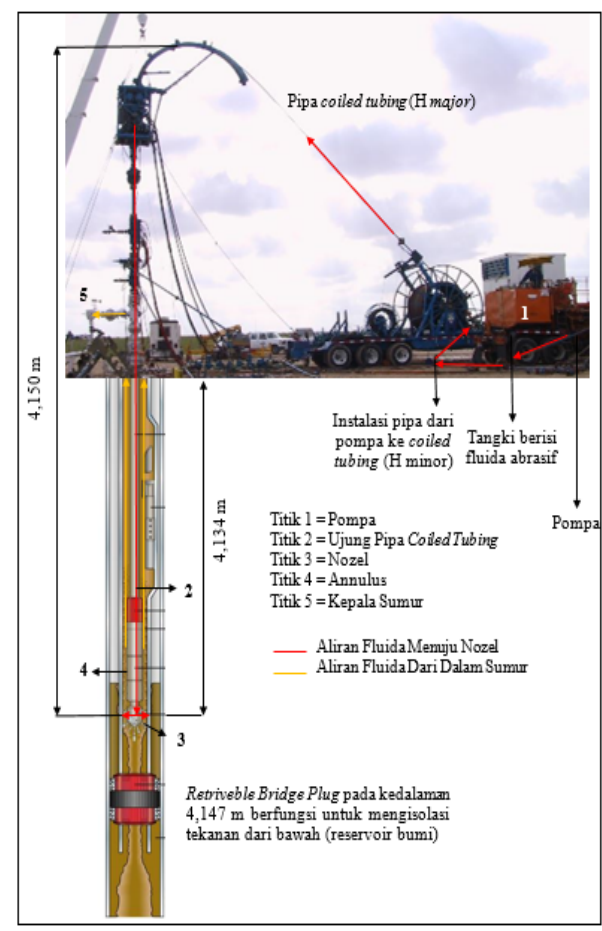

Gambar 17. Instalasi Pemotongan Pipa Produksi Dengan Teknik Hydrajetting

\section{Pengolahan Data}

- Perhitungan Kerapatan (Density) Fluida Campuran

$$
\rho_{\mathrm{c}}=\frac{1}{1+\frac{P P A}{\rho P \text { Pasir }}}(\rho \operatorname{air}+\mathrm{PPA})
$$

$$
\begin{aligned}
& \rho_{c}=\frac{1}{1+\frac{1}{22.1}}(8.34+1) \\
& \rho_{c}=8.935 \text { PPG }=1071 \mathrm{~kg} / \mathrm{m}^{3}
\end{aligned}
$$

\section{- Perhitungan Berat Fluida}

$$
\begin{aligned}
& \gamma=\rho \times g \\
& \gamma=1071 \mathrm{~kg} / \mathrm{m}^{3} \times 9.81 \mathrm{~m} / \mathrm{s}^{2}=10506.51 \mathrm{~N} / \mathrm{m}^{3}
\end{aligned}
$$

\section{- Perhitungan Laju Aliran}

Dengan menggunakan persamaan kontinuitas

\begin{tabular}{|c|c|c|c|c|c|c|}
\hline Debita alima $\left(\mathrm{m}^{3} / \mathrm{s}\right.$ & $V_{l}(\mathrm{~ms}$ & $\mathrm{V}_{2}(\mathrm{~ms})$ & $V_{\text {hydradyat }}(\mathrm{m} / \mathrm{s}$ & $V_{3(\text { mis })}$ & $\mathrm{V}_{4}(\mathrm{~m} / \mathrm{s})$ & $\mathrm{V}_{5}(\mathrm{~m})$ \\
\hline 0.0026 & 1.6 & 1.6 & 5.2 & 48.7 & 0.5 & 5.2 \\
\hline 0.0039 & 2.4 & 2.4 & & 73 & 0.68 & 7.7 \\
\hline 0.0052 & 3.2 & 3.2 & 10.2 & 97.4 & 0.9 & 10.2 \\
\hline 0.0061 & 3.8 & 3.8 & 12 & 114 & 1 & \\
\hline
\end{tabular}
maka didapatkan data hasil perhitungan kecepatan aliran dengan menggunakan debit debit yang berbeda :

Tabel 4. Laju Aliran pada tiap titik

- Rugi Rugi Energi

$\mathrm{H}_{\mathrm{L}}$ coiled tubing + instalasi pipa

$\mathbf{H}_{\mathbf{L}}=\mathbf{H}_{\text {major }}+\mathbf{H}_{\text {minor }}$

$H_{L}=2074 m+10 m=2084 m$

$\mathrm{H}_{\text {major hydrablast }}=\mathbf{3 8} \mathrm{m}$

$H_{\text {major annular }}=140 \mathrm{~m}$

\begin{tabular}{|c|c|c|c|c|}
\hline$b_{t}\left(\mathrm{~m}^{3} / \mathrm{s}\right)$ & $P_{1}\left(\mathrm{Nm}^{2}\right)$ & $\mathrm{P}_{2}\left(\mathrm{Nm}^{2}\right)$ & $P_{\text {evtinghnod }}\left(\mathrm{Im}^{2}\right.$ & $\mathrm{P}_{3}\left(\mathrm{Nm}^{2}\right.$ \\
\hline 0.0026 & 2413000 & & 6001 & 5955 \\
\hline 0.039 & 5380 & & & \\
\hline 0,0052 & 46190000 & 67840716 & 67429721 & 6240935 \\
\hline 0.006 & 49640000 & 67829481 & 67880876 & 6297356 \\
\hline
\end{tabular}

\section{- Perhitungan Tekanan}

Tekanan $\mathrm{P}_{1}, \mathrm{P}_{2}, \mathrm{P}_{\text {cutting head }}$ dan $\mathrm{P}_{3}$ disebut tekanan upstream.

Tabel 5. Tekanan Upstream

Tekanan $\mathrm{P}_{4}$ dan $\mathrm{P}_{5}$ disebut tekanan downstream.

Tabel 6. Tekanan Downstream

\begin{tabular}{|c|c|c|}
\hline Debit $\left(\mathrm{m}^{3} / \mathrm{s}\right)$ & $\mathrm{P}_{4}\left(\mathrm{~N} / \mathrm{m}^{2}\right)$ & $\mathrm{P}_{5}\left(\mathrm{~N} / \mathrm{m}^{2}\right)$ \\
\hline 0.0026 & 45266018 & 344000 \\
\hline 0.0039 & 44778975 & 758000 \\
\hline $\mathbf{0 . 0 0 5 2}$ & $\mathbf{4 6 2 2 6 0 2 3}$ & $\mathbf{1 0 3 4 0 0 0}$ \\
\hline 0.0061 & 46358409 & 1379000 \\
\hline
\end{tabular}

- Perhitungan Perbedaan Tekanan Pada Kedalaman Potong

Dengan menggunakan rumus :

$\Delta \mathrm{P}=\mathrm{P} 4$ (tekanan annulus) $-\mathrm{P}_{\text {cutting head }}$ maka didapat perbedaan tekanan $(\Delta \mathrm{P})$ pada kedalaman potong dengan menggunakan debit debit yang berbeda sebagai berikut : 
Tabel 7. Perbedaan Tekanan Pada Kedalaman Potong

\begin{tabular}{|c|c|c|c|c|}
\hline Debit $\left(\mathrm{m}^{3} / \mathrm{s}\right)$ & $\mathrm{P}_{\text {cutting hazd }}\left(\mathrm{N} / \mathrm{m}^{2}\right)$ & $\mathrm{P}_{4}\left(\mathrm{Nm}^{2}\right)$ & $\Delta \mathrm{P}\left(\mathrm{N} / \mathrm{m}^{2}\right)$ & $\Delta \mathrm{P}(\mathrm{psi})$ \\
\hline 0.0026 & 60812959 & 45266018 & 155469441 & 2254 \\
\hline 0.0039 & 63994922 & 44778975 & 19215947 & 2787 \\
\hline 0.0052 & 67429722 & 46226023 & 21203699 & 3075 \\
\hline 0.0061 & 67880876 & 46358409 & 21522467 & 3121 \\
\hline
\end{tabular}

- Perhitungan Slip Velocity $\mathrm{SV}=0.04 \mathrm{~m} / \mathrm{s}$

- Perhitungan Annular Velocity (AV)

Rekomendasi

$\mathrm{AV}=\mathrm{SV} \times$ Safety Factor

$\mathrm{AV}=0.04 \mathrm{~m} / \mathrm{s} \times 5=0.2 \mathrm{~m} / \mathrm{s}$

- Perhitungan Jetting Force

Perhitungan jetting force dengan menggunakan debit debit yang berbeda.

Tabel 8. Jetting Force

\begin{tabular}{|c|c|c|}
\hline Debit $\left(\mathrm{m}^{3} / \mathrm{s}\right)$ & $\Delta \mathrm{P}\left(\mathrm{N} / \mathrm{m}^{2}\right)$ & Jetting Force $(\mathrm{N})$ \\
\hline 0.0026 & 14292078 & 235 \\
\hline 0.0039 & 16392506 & 261 \\
\hline $\mathbf{0 . 0 0 5 2}$ & $\mathbf{1 6 1 8 3 3 3 3}$ & $\mathbf{2 8 9}$ \\
\hline 0.0061 & 16615154 & 298 \\
\hline
\end{tabular}

- Perhitungan Tekanan Burst Pipa dan Gaya (Force) Burst Pipa

Mencari tekanan burst

$\mathbf{P}_{\text {burst pipa }}=\frac{2 \times \mathrm{MTS} \times \mathrm{t}}{}$

$\mathbf{P}_{\text {burst pipa }}=\frac{2 \mathrm{P} \times 108000 \times 0.29}{4.5 \times 1}=12889$ psi

Mencari gaya burst

$\mathbf{F}_{\text {burst pipa }}=\mathbf{P}_{\text {burst pipa }} \times \mathbf{A}_{\text {Nozel }}$

$F_{\text {burst pipa }}=12889$ psi $x 1 / 4 \pi(0.1875 \text { in })^{2}$

$F_{\text {burst pipa }}=356$ lbs $=1584 \mathrm{~N}$

- Perhitungan Waktu Pemotongan

Pada saat pemotongan pipa produksi sumur, alat HydraBlast $^{T M}$ berputar dengan RPM tertentu. Putaran ini dapat terjadi dikarenakan profil nozel, tekanan dan aliran yang terjadi. Nilai RPM aktual ini tidak diketahui karena putaran motor berada dalam sumur, maka untuk menghitung waktu pemotongan pipa diasumsikan nozel berada dalam keadaan diam tidak berputar tetapi dikondisikan untuk mencakup keseluruhan keliling pipa produksi.

- Mencari keliling pipa produksi

$2 \pi \mathrm{r}=\pi \mathrm{D}=\pi 114.3 \mathrm{~mm}=359 \mathrm{~mm}$

- Mencari lebar lubang yang terjadi pada pipa produksi

Lebar lubang yang terjadi $=2 \times 4.76 \mathrm{~mm}=$ $9.52 \mathrm{~mm}$
- Mencari waktu membuat 1 lubang pada pipa produksi

$F_{\text {burst pipa }} / F_{\text {Jetting }}=(9.52 \mathrm{~mm} / 4.76 \mathrm{~mm}) x$ $1584 \mathrm{~N} / 289 \mathrm{~N}=11 \mathrm{~s}$

- Mencari berapa banyak lubang yang dibutuhkan

Keliling pipa $/$ lebar lubang $=359 / 9.52=$ 38 lubang

- Mencari berapa kali proses pelubangan dengan 3 nozel

38 lubang $/ 3$ nozel $=13$

- Mencari berapa lama pipa produksi akan terpotong

13 kali x $11 \mathrm{~s}=143 \mathrm{~s}=2.4$ menit

Safety factor $=2.4$ menit $x 3=7.2$ menit 8 menit

\section{- Perhitungan Standoff}

Mencari jarak standoff pada saat cutting head menempel pada dinding pipa produksi

Jarak Standoff $=$ D pipa produksi $-\mathbf{d}$ cutting head

Jarak Standoff $=99.56 \mathrm{~mm}-73 \mathrm{~mm}=26.56$ mm

Mencari jarak standoff pada saat sumbu cutting head berada sejajar sumbu pipa produksi

Jarak Standoff $=(\mathrm{D}$ pipa produksi $-\mathbf{d}$ cutting head) / 2

Jarak Standoff $=(99.56 \mathrm{~mm}-73 \mathrm{~mm}) / 2=$ $13.28 \mathrm{~mm}$

\section{ANALISIS HASIL DAN PEMBAHASAN}

Hasil perhitungan dianalisis dan dibandingkan terhadap ketentuan yang baku atau standar acuan mengenai syarat-syarat atau rekomendasi proses pemotongan pipa produksi sumur dengan teknik Hydrajetting. Selain itu dianalasis ketentuan-ketentuan lain yang menjadi syarat keberhasilan proses Hydrajetting ini. 
Tabel 9. Rekomendasi Hydrajetting

\begin{tabular}{|c|c|}
\hline General Recommendations & Pipe Cutting Application \\
\hline Jet Diameter & $3 / 16$ in or $1 / 4$ in \\
\hline Jet Phasing & $120^{\circ}$ \\
\hline $\begin{array}{l}\text { Jet Differential Pressure (UP) } \\
\text { Across Nozzle }\end{array}$ & $\begin{array}{l}\text { - minimum } 3,000 \text { psi at } 1 \text { bpm for } 3 / 1 / 6 " \text { nozzle } \\
\text { - minimum } 3000 \text { psi at } 2 \text { bpm for '/4" nozzle } \\
\text { (jet pressure of } 1000 \text { psi will create plugging at the nozzle) }\end{array}$ \\
\hline Optimum Standoff & 6 x Jet Diameter or less \\
\hline Efficient Jet Stream Distance & 10-40x Jet Diameter \\
\hline Effective Penetration Distance & $11.25 \mathrm{in}$ \\
\hline Stream loses effectiveness & Approximately 60 y jet diameter \\
\hline Hole Diameter Result & $\begin{array}{l}\text { Perforation }=3 \times \text { Jet Diameter } \\
\text { Pipe cutting }=2 \times \text { Jet Diameter }\end{array}$ \\
\hline Annular velocity & $5 x$ slip velocity \\
\hline Proppant Concentration. & IPPA \\
\hline Jetting Fluid & 20 HLinear $\mathrm{Gel}$ \\
\hline Jetting Tine & 10. 15 mintles (single string of pipe cutting) \\
\hline
\end{tabular}

\section{Analisis Laju Aliran Fluida Dalam Saluran}

Perhitungan laju aliran fluida dalam saluran menggunakan teori hukum kontinuitas mulai dari laju aliran pada instalasi perpipaan setelah pompa, kemudian masuk ke dalam pipa coiled tubing, kemudian keluar melalui nozel dan sampai akhirnya keluar di kepala sumur

- Titik 1 = pangkal coiled tubing

- Titik 2 = ujung coiled tubing

- Hydrablast ${ }^{T M}=$ alat Hydrajetiting

Titik $3=$ nozel

- Titik 4 = anulus pada kedalaman potong

- Titik 5 = kepala sumur

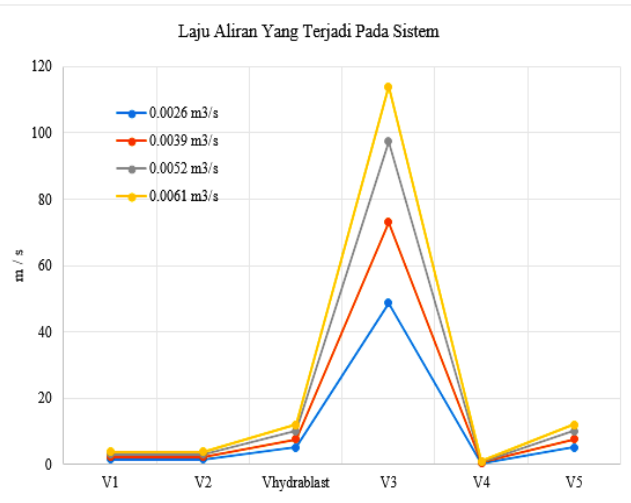

Gambar 18. Laju Aliran Pada Tiap Titik

Dari gambar 18, terlihat bahwa beberapa debit aliran akan menghasilkan kecepatan aliran yang berbedabeda sesuai dengan besar area saluran yang dilaluinya. Dengan debit yang sama di setiap titik pada instalasi, maka sesuai hukum kontinuitas pada nozel dihasilkan laju aliran yang paling cepat dan di anulus dihasilkan laju aliran yang paling lambat.
Analisis Laju Aliran Di Anulus (Annular Velocity) Terhadap Slip Velocity

Pada proses pemotongan pipa produksi, pasir yang menjadi bahan abrasif dalam fluida dan debris cutting yang terjadi dari hasil pemotongan tidak boleh mengendap di dalam sumur. Pasir yang dipompakan harus dapat terbawa kembali ke permukaan. Pasir dan debris cutting yang mengendap akan mengakibatkan proses pencabutan Retrievable Bridge Plug yang mengisolasi produksi sumur sementara akan sulit dikarenakan pasir akan menimbun permukaan Retrievable Bridge Plug. Selain itu pasir yang tidak terangkat akan menjadi residu bagi sumur sehingga proses produksi sumur akan terganggu. Kecepatan anular yang kurang akan mengakibatkan partikel-partikel pasir dan debris cutting jatuh (slip) kembali ke dasar sumur. Oleh karena itu kecepatan anular harus lebih besar dari pada kecepatan slip (slip velocity) sesuai rekomendasi standar acuan proses pemotongan pipa dengan teknik Hydrajetting.

- slip velocity $=0.04 \mathrm{~m} / \mathrm{s}$

- Rekomendasi annular velocity dengan safety factor 5 x slip velocity $=0.2 \mathrm{~m} / \mathrm{s}$

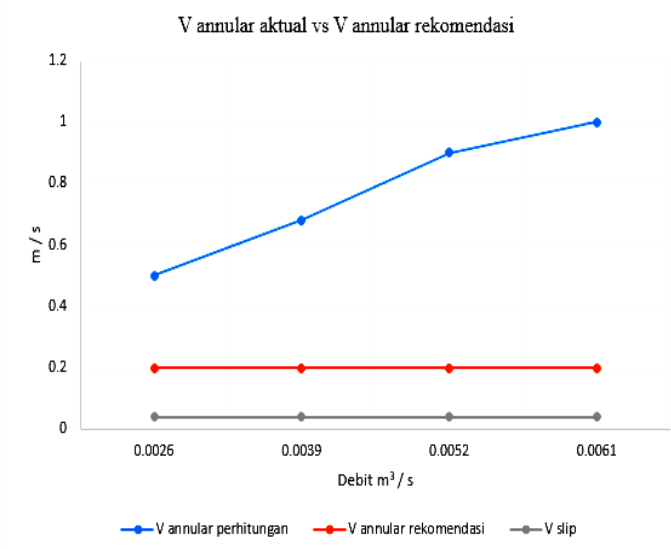

Gambar 19. Annular Velocity vs Slip Velocity

Dari gambar 19, terlihat bahwa semua debit aliran akan menghasilkan kecepatan anular yang diatas batas rekomendasi sehingga jika dilihat dari aspek kecepatan anular semua debit aliran dapat digunakan dan dipastikan pasir yang dipompakan dan debris cutting yang dihasilkan dapat terbawa ke permukaan.

\section{Analisis Tekanan}

Perhitungan tekanan yang terjadi di dalam sistem dilakukan dengan menggunakan persamaan energi Bernoulli dimana dipengaruhi percepatan grafitasi, elevasi dan rugi rugi. Untuk menganalisis tekanan yang terjadi, maka instalasi dibagi dua menjadi tekanan upstream yaitu tekanan yang terjadi mulai 
dari pompa, coiled tubing, alat HydraBlast ${ }^{T M}$ dan pada akhirnya ujung nozel, dan tekanan downstream yang terjadi pada anulus hingga pipa keluaran kepala sumur.

- Titik 1 = pangkal coiled tubing

- Titik 2 = ujung coiled tubing

- Cutting Head = kepala potong

Titik $3=$ nozel

- Titik 4 = anulus pada kedalaman potong

- Titik 5 = kepala sumur

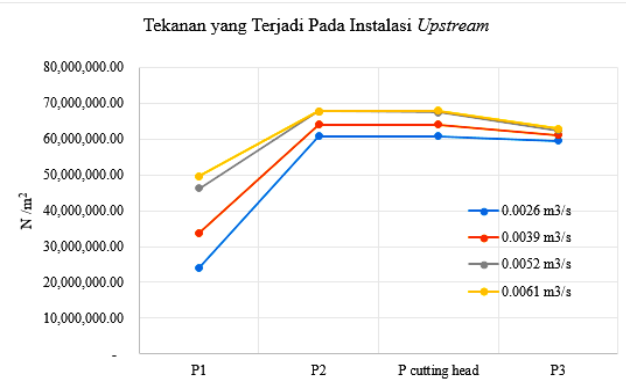

Gambar 20. Tekanan Upstream

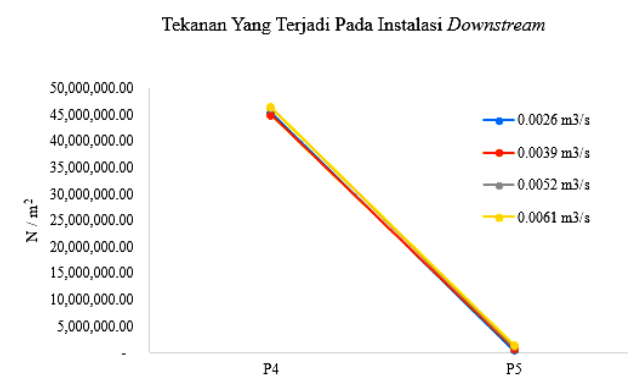

\section{Gambar 21. Tekanan Downstream}

Dari gambar 20 dan 21, terlihat bahwa beberapa debit aliran akan menghasilkan tekanan yang berbeda-beda pada tiap titik.

- Tekanan awal $\mathrm{P}_{1}$ yang diberikan pompa akan menghasilkan tekanan $\mathrm{P}_{2}$ yang lebih besar dikarenakan adanya elevasi dan rugi rugi.

- Tekanan $\mathrm{P}_{2}$ kemudian akan diturunkan menjadi tekanan $\mathrm{P}_{\text {cutting head }}$ dan $\mathrm{P}_{3}$ sesuai hukum Bernoulli dimana tekanan akan menjadi lebih kecil seiring fluida bertekanan melewati saluran yang lebih kecil.

- Tekanan $\mathrm{P}_{4}$ merupakan tekanan di anulus pada kedalaman potong dan akan turun menjadi tekanan $\mathrm{P}_{5}$ seiring fluida bergerak ke permukaan sehingga elevasi dan rugi rugi berpengaruh di dalamnya.

\section{Analisis Perbedaan Tekanan ( $\Delta \mathrm{P})$ Pada Kedalaman Potong \\ Syarat berhasilnya proses pemotongan pipa produksi sumur dengan teknik Hydrajetting dilihat dari aspek}

tekanan adalah terjadinya perbedaan tekanan $\Delta \mathrm{P}$ (differential pressure) antara tekanan di cutting head dengan tekanan anulus pada kedalaman potong. Perbedaan tekanan $\Delta \mathrm{P}$ yang direkomendasikan adalah minimum $3000 \mathrm{psi}$ atau $2.068 \times 10^{7} \mathrm{~N} / \mathrm{m}^{2}$.

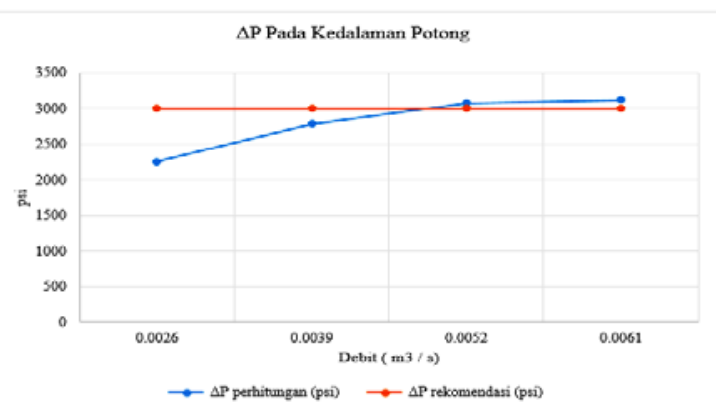

Gambar 22. $\triangle \mathrm{P}$ Pada Kedalaman Potong

Dari gambar 22, terlihat bahwa tidak semua debit aliran akan menghasilkan perbedaan tekanan $(\Delta \mathrm{P})$ pada kedalaman potong yang sesuai dengan rekomendasi. Debit aliran yang dapat menghasilkan perbedaan tekanan sesuai rekomendasi hanya $\mathrm{Q}=$ $0.0052 \mathrm{~m}^{3} / \mathrm{s}$ dengan $\Delta \mathrm{P}$ sebesar 3075 psi dan $\mathrm{Q}=$ $0,0061 \mathrm{~m}^{3} / \mathrm{s}$ dengan $\Delta \mathrm{P}$ sebesar 3121 psi. Dengan demikian debit aliran pemompaan yang dapat digunakan hanya pada batasan $0.0052 \mathrm{~m}^{3} / \mathrm{s}-0,0061$ $\mathrm{m}^{3} / \mathrm{s}(2-2.3 \mathrm{bpm})$.

\section{Analisis Standoff}

Pada pekerjaan coiled tubing tidak akan terjadi kondisi standoff yang maksimal dikarenakan faktor residual bend dari coiled tubing yang selalu membuat alat yang dibawanya bersandar atau menempel pada dinding sumur. Untuk mendapatkan standoff yang optimum pada alat HydraBlast ${ }^{T M}$ dipasang Hydraulic Centralizer yang berfungsi untuk memposisikan alat Hydrablast ${ }^{T M}$ cenderung ditengah-tengah pipa produksi. Jarak yang dihasilkan oleh posisi standoff berpengaruh terhadap faktor lain yaitu efisiensi jet stream dan jarak efektif penetrasi. Rekomendasi jarak Standoff yang optimal adalah $6 \mathrm{x}$ diameter nozel atau lebih kecil.

Hasil perhitungan Standoff :

- Lebar Jarak Standoff pada saat nozel bersandar pada dinding pipa produksi sebesar $26.56 \mathrm{~mm}$ $(1.04$ inch $)=5.6 \mathrm{x}$ diameter nozel

- Lebar Jarak Standoff pada saat nozel berada satu sumbu dengan sumbu pipa produksi sebesar $13.28 \mathrm{~mm}(0.52 \mathrm{inch})=2.8 \mathrm{x}$ diameter nozel Jadi jarak standoff yang terjadi pada proses pemotongan baik dalam kondisi nozel menempel pada dinding maupun ditengah-tengah pipa produksi menghasilkan lebar jarak standoff yang masih dalam jarak optimum jangkauan proses Hydrajetting. 


\section{Analisis Waktu Pemotongan Pipa Produksi}

Waktu pemotongan menjadi salah satu kriteria yang menentukan dalam keberhasilan proses pemotongan pipa produksi. Waktu pemotongan yang lama membutuhkan jumlah fluida yang banyak sedangkan waktu pemotongan yang sebentar mengakibatkan kemungkinan keberhasilan pemotongan menjadi dipertanyakan. Rekomendasi waktu pemotongan pipa produksi dengan teknik Hydrajetting adalah 10-15 menit.

Hasil Perhitungan Waktu Pemotongan

- Dengan debit $\mathrm{Q}=0.0052 \mathrm{~m}^{3} / \mathrm{s}$ akan menghasilkan waktu pemotongan pipa produksi sumur selama 8 menit

- Waktu aktual yang terjadi di lapangan sesuai program kerja adalah 20 menit.

Jadi waktu proses pemotongan yang terjadi di lapangan melebihi dari waktu rekomendasi dan waktu hasil perhitungan. Sehigga dipastikan pipa produksi terpotong secara sempurna.

\section{KESIMPULAN}

Berdasarkan hasil analisis dan pembahasan mengenai perbandingan antara hasil perhitungan dengan rekomendasi atau standar acuan proses pemotongan pipa produksi dengan teknik Hydrajetting, maka dihasilkan data data sebagai berikut :

1. Penggunaan debit aliran $0.0052 \mathrm{~m}^{3} / \mathrm{s}$ dan 0.0061 $\mathrm{m}^{3} / \mathrm{s}$ akan menghasilkan kecepatan anular yang diatas standar acuan kecepatan anular sehingga dapat menanggulangi permasalahan slip velocity. Dengan kondisi ini pasir dan debris cutting tidak akan jatuh ke dasar sumur sehingga tidak mengganggu proses pengerjaan selanjutnya atau proses produksi sumur.

2. Penggunaan debit aliran $0.0052 \mathrm{~m}^{3} / \mathrm{s}$ dan 0.0061 $\mathrm{m}^{3} / \mathrm{s}$ akan menghasilkan perbedaan tekanan $(\Delta \mathrm{P})$ pada kedalaman potong sesuai dengan standar acuan pada tekanan minimum 3000 psi.

3. Kondisi Standoff pada proses pemotongan pipa produksi dengan teknik Hydrajetting pada pipa produksi 4.5 inch akan memberikan jarak standoff sebesar 5.6 x diameter nozel dimana jarak ini masih dalam berada di dalam batas standar acuan.

4. Penggunaan debit $0.0052 \mathrm{~m}^{3} / \mathrm{s}$ membutuhkan waktu selama 8 menit untuk memotong pipa produksi sehingga waktu aktual di lapangan selama 20 menit sangat cukup untuk memastikan pipa produksi sudah berhasil terpotong dengan sempurna.

5. Penggunaan debit $0.0052 \mathrm{~m}^{3} / \mathrm{s}$ dan $0.0061 \mathrm{~m}^{3} / \mathrm{s}$ terbukti dapat memotong pipa produksi sumur dengan sempurna sehingga proses pemompaan di lapangan dilakukan pada batasan $0.0052 \mathrm{~m}^{3} / \mathrm{s}$ - 0,0061 $\mathrm{m}^{3} / \mathrm{s}(2-2.3 \mathrm{bpm})$.
Kesimpulan di atas menunjukan bahwa penggunaan aplikasi proses pemotongan pipa produksi sumur dengan teknik Hydrajetting terbukti dapat memotong pipa produksi sumur dengan sempurna. Selain itu aplikasi ini dapat menjadi suatu solusi yang terukur untuk menanggulangi permasalahan penurunan produksi sumur yang diakibatkan oleh kerusakan yang terjadi pada pipa produksi.

\section{DAFTAR PUSTAKA}

1. Sharlene Lindsay, Hydra-Jet Playbook, Halliburton, Houston, Texas 2011

2. Muhammad Haekal, BC-PRE-021-2014-V3 GHZL-7 2" HPCT Intervention for Work Over Well, Saudi Arabia, 2014

3. Barlow's Formula for theoritical burst perssure tubing, 2016

4. Halliburton, CAST-M Ultrasonic Tubing Casing Evaluation, Texas 2013

5. Kementerian Pendidikan dan Kebudayaan Republik Indonesia, Dasar-Dasar Teknik Pengeboran, Jakarta, 2013

6. Halliburton, Hydra Blast ${ }^{T M}$ - Hydrajetting Pro Cleaning Welbore Tubular, Texas, 2015

7. Robert Wade Brown, SPE001572 - Theory of Formation Cutting Using Sand Erosion Process, Dallas Texas

8. Halliburton, 2.88-in. OD HydraBlast ProTM Tool Assembly and Operating Instructions, United States of America, 2008

9. Halimatuddahliana, Jurnal Pencegahan Korosi Dan Scale Pada Proses Produksi Minyak Bumi, Universitas Sumatera Utara, 2003

10. Motor Handbook, National Oilwell Varco, Canada, 2007

11. Dr. Jim B. Surjaatmadja, Technology Bulletin, Best Practive For Proppant Jetting During Fracturing and Hydrajet Perofating and Cutting, Halliburton, Duncan OK, 2011

12. Rully Ade Iswadi, Jurnal Analisa Pompa Bertekanan Tinggi Untuk Proses Pemotongan Tubing, Jurusan Teknik Mesin, FTI Universitas Jayabaya, 2015

13. SPF-243 Stimulation Pumper Float - High Pressure Pumping System, Schlumberger, 2006

14. H09149 Twin Panther PT SDS, Halliburton, 2012

15. H00924 CAST-M / CBL / MFC, Halliburton, 2013 